\title{
HIV-related criminal cases based on fear, not science, say advocates
}

Published at www.cmaj.ca on Aug. 3

$\mathrm{M}$ any of the criminal cases involving HIV-positive people who don't disclose their status are based on 1980s-era panic rather than sound science, according to advocates of people living with HIV/AIDS in Canada.

The high number of unwarranted charges and confusion around what does and does not constitute an offence is also likely to set back gains made in prevention and antistigma campaigns, say groups such as the Canadian Legal HIV/AIDS Network, Ottawa Gay Men's Wellness Initiative and the AIDS Committee of Toronto.

"The legislation should be informed by scientific guidelines about risk and not driven by panic or phobia," says Richard Elliott, executive director of the Canadian Legal HIV/AIDS Network.

However, Inspector Joan McKenna, cochair of the Ottawa Police Service's Liaison Committee for Lesbian, Gay, Bisexual and Transgender, says the law is straightforward. "If there is nondisclosure, that's the big issue. If you disclose, there is no problem."

The Joint United Nations Programme on HIV/AIDS (UNAIDS) has recommended that cases should be prosecuted only when actual transmission has occurred. The international body also says convictions should occur only when "malicious intent" can be proven. In other words, those who selfishly prioritize unprotected sex over their partner's health should be held liable, but those who don't disclose for other reasons, such as a lack of awareness about how HIV is spread, should not be criminally prosecuted.

"Regardless of the risk you're exposing someone to, if you quite realistically fear that you will be beaten up if you disclose your status, then you shouldn't be held criminally liable for not disclosing," says Elliott.

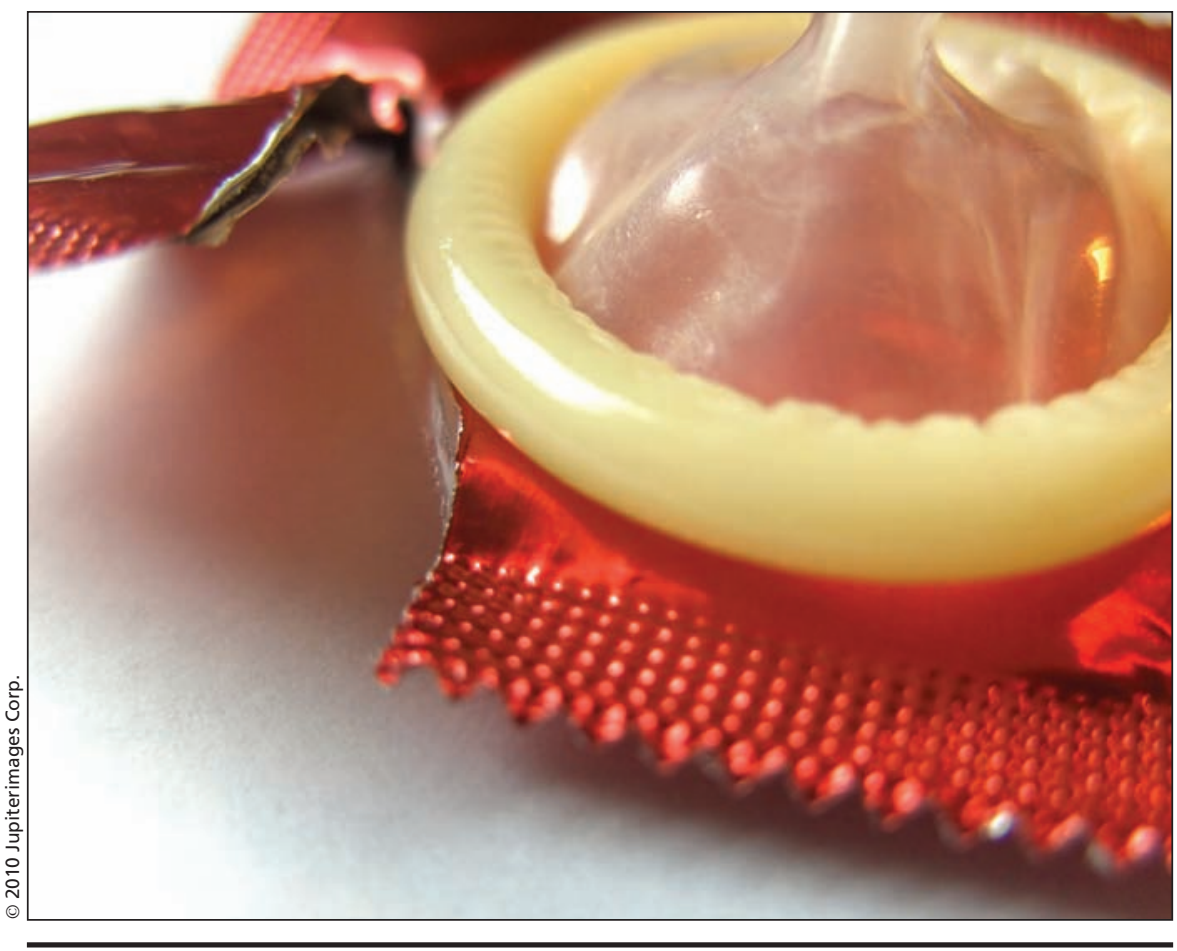

Several trial judges in Canada have stated that disclosure of HIV-positive status is not required when a condom is used.

During last month's XVIII International AIDS Conference in Vienna, Austria, a panel on HIV criminalization noted that 600 cases involving exposure or transmission have been recorded around the world; but the actual number is likely higher. In Canada, the Canadian HIV/AIDS Legal Network reports that there have been 100 criminal cases.

Despite the UNAIDS recommendation, Canada and many other countries prosecute people for putting others at a risk of HIV, not just spreading the virus. Individuals have been prosecuted for acts where transmission of HIV would be impossible or extremely unlikely. In 2008, an HIV-positive Texas man was sentenced to 35 years for spitting at a police officer. In several countries, including Canada, Singapore and the US, HIV-positive individuals have faced judges for engaging in unprotected oral sex.
The Supreme Court of Canada has stated that convictions should only occur when the accused put the victim at "significant risk" of contracting HIV. However, what is and what is not considered a "significant risk" is up to individual judges to decide.

As a result, oral sex can be considered a "significant risk" in one case and not worth prosecuting in another. In the 2009 case of Johnson Aziga, the first man in Canada to be convicted of murder for not disclosing that he was HIVpositive, one of his "aggravated assault" convictions was based on the fact that he had oral sex with a woman, even though she did not become infected. However, in April, the crown stayed charges against an HIV-positive man who had oral sex without telling his partner on the grounds that the risk involved was too low.

While Elliott says that only prose- 
cuting cases involving transmission would be "a sensible place to draw the line," given that Canada's justice system has already decided exposure to HIV counts as a legitimate legal issue, his organization is urging Canada's justice system to set reasonable, sciencebased limits on when exposure amounts to a "significant risk."

The HIV/AIDS Legal Network argues that if, for example, someone practises safer sex, criminal charges for not disclosing are not justified. While several trial judges have stated that disclosure is not required when a condom is used, at least two men in Canada have been convicted of aggravated sexual assault for not disclosing their status even though they wore a condom during vaginal sex, according to Elliot.

"If on the one hand, the key public health message is 'practise safer sex, protect yourself' and on the other hand people are criminally charged when they practise safe sex, that is a completely contradictory message."

While there is no statistical evidence on how the recent spate of criminal HIV-related cases affects health-seeking behaviours, Elliott thinks the hard line Canada's courts have taken could discourage people from testing themselves. Those who have tested positive, perhaps at an anonymous site, may also be less likely to seek out medical services and counselling for fear their health providers will turn them over to the police, according to Elliott.

"It puts up a barrier in the relationship between the health provider and the individual," says Elliott, who adds that public health professionals are uncertain about their own responsibility to report patients, given the lack of clear guidelines. "People are asking us, 'How does it affect the therapeutic role if I have to play the role of cop?'."

Last week, Brent Bauer of the
Ottawa Gay Men's Wellness Initiative complained to the Ottawa police board that they had infringed on privacy when they released a photo of 29-yearold Steven Paul Boone, a man who allegedly infected an 18-year-old man and may have infected others.

But McKenna says the police weighed the interests of "community safety" over Boone's privacy in their decision to share his photo. "It is important that his past partners have this information that affects their own personal health."

Elliott suggests that public health authorities, rather than police, should intervene in all but the most egregious of cases. "It's a more flexible way of intervening. [Public health authorities] can order people into counselling. They take into account mental health issues." - Wendy Glauser, Toronto, Ont.

DOI:10.1503/cmaj.109-2235 